\title{
Congress and administration differ over views of threats to science
}

Washington. Leaders of the US scientific community, eager for reassurance in difficult times and impressed in particular by the strong personal support of Vice President Al Gore, last week gave a warm welcome to the administration's science policy statement, Science in the National Interest (see Nature 370, 317; 1994).

But the most notable specific pledge in the document - a half-hearted promise to raise science spending to three per cent of gross domestic product (GDP) - was quickly shot down in flames in Congress, while sceptics complained that the paper does little to protect science from the growing propensity of Congress to direct scientific research.

According to White House officials, the document's assertion that "a reasonable long term goal for the total national research and development [R\&D] investment (both civilian and military) might be about three per cent of GDP" was not meant to be a hard target. But it quickly became one.

At the launch of the document last Wednesday (3 August), for example, M. R. C. Greenwood of the Office of Science and Technology Policy (OSTP), chose to focus on the three per cent goal, while adding that achieving it was going to require "an unprecedented effort by government and the private sector".

But it did not take long for George Brown (Democrat, California), chairman of the House of Representatives Science, Space and Technology Committee, to remind

Greenwood just how unprecedented the effort would have to be. At a hearing the following day, Brown produced some backof-an-envelope calculations suggesting that in order to achieve the target, the government's spending on civil R\&D would have to grow by 80 per cent - to $\$ 47.75$ billion - by 1998 .

"I concur with you that it's a challenge," John Gibbons, director of OSTP, told Brown rather lamely. "We're very interested in seeing how some of these figures work out."

The three per cent target was included in the document because OSTP badly needed some specifics to go with all the fine words.

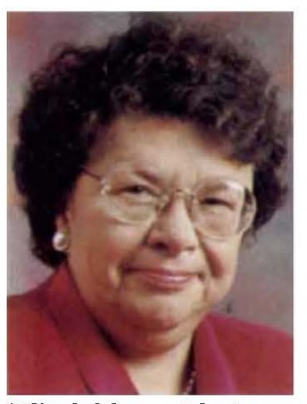

Mikulski: seeking control of NSF?
But some remain unimpressed by a policy statement which, in the harsh words of one Senate staffer, "hasn't got any policy in it".

The last such document, presented by President Jimmy Carter in 1979 , brimmed with promises of more cash, especially for energy research. This time the OSTP says that the intent is different, namely to make a public case for science. Greenwood describes it as "a call to arms" for a scientific community that perceives itself as under threat.

Opinions differ on whether the threat is

\section{Fast reactors 'could rise from ashes'}

Paris. Superphénix, the world's largest prototype fast breeder reactor, was kicked into operation last week at Creys-Malville near Lyons for the first time in four years, just days after the French government had approved its conversion from a power station into a research reactor.

The decision to restart the 1,200-MW reactor appears primarily to have been a political solution to the need to satisfy NERSA, the French, German and Italian consortium that owns the reactor. NERSA has paid FF27.7 billion (US\$5 billion) to build the reactor, which has operated for a total of less than six months; it was shut down in 1990 after repeated leaks in its sodium cooling circuits.

Half of the programme's FF100 million annual budget will be spent converting the fast neutron reactor from a breeder to a consumer of plutonium. This will be done by equipping it with cores lacking a uranium blanket, within the CAPRA (Consommation Accrue de Plutonium dans les Rapides) programme started by the French Atomic Energy Commission last autumn.

A third of the funding will go to studies on incinerating minor actinides, such as neptunium, and one-fifth to safety studies.

Adrien Mergui, president of the directors of NERSA, claims that the restart of Superphénix will help to restore some of the lost momentum in the development of fast breeders. He predicts a resurgence of interest in fast breeders, given the inevitable - if more distant than previously been expected - shortage of uranium resources. The planned research at Superphénix, he says, will provide the groundwork for the European Fast Reactor programme, abandoned last year, to rise from the ashes.

Declan Butler

See also page 404. real. There are two main funding agencies for basic research in the United States. Funding for the National Institutes of Health (NIH) is virtually guaranteed by congressional support for its work. So the smaller National Science Foundation (NSF) is the key battleground for science policy; and it is still not clear whether its independence is under threat from Congress.

NSF officials feel that the issue has receded since last autumn's attempt by a key Senate appropriations subcommittee to direct more of the agency's work towards strategic research. Since then, Barbara Mikulski(Democrat, Maryland), who chairs the subcommittee, has warmly praised the agency's director, Neal Lane, and backed large budget increases.

But Robert Park, of the American Physical Society, claims that the battle for the soul of NSF is continuing - and that Mikulski is winning. He points out that an NSF reauthorization bill, drafted chiefly by Mikulski and likely to be passed by the Senate, will require 60 per cent of the agency's funds to be devoted to "strategic goals".

These include favourites such as environmental research alongside less familiar entities, such as "civil infrastructure", which covers research intended to help repair crumbling roads and sewers and attracts the largest increases -20 per cent a year, compounded over five years - in the bill.

The bill is unlikely to pass into law, as it is significantly different from the version under consideration by the House. But the approval of Mikulski's version by the Senate alone will lend authority to her committee's future budget decisions.

The change means that NSF money will be authorized in two ways, by mission and by discipline. NSF grant applications are already being categorized in this manner. But Park thinks the change is dangerous, because although Congress has tended to leave disciplines alone, it will feel free to tamper with missions. "It gives Mikulski control over NSF," he says.

Lane himself points to language in the bill which gives him, as director, power to revise the strategic goals. He says that the bill gives the NSF sufficient flexibility to readjust the areas concerned, and that such areas "are precisely the ones which we, at NSF, identified".

The impact of both Mikulski's reauthorization bill and the White House policy document will be measured by the principles they establish, not the dollars they specify. And, at present, it seems to be Mikulski who is making the running.

Colin Macilwain 